\title{
Doha development agenda: implications for the US and world cotton markets
}

\author{
Mohamadou L. Fadiga*, Samarendu Mohanty, Mark Welch and \\ Suwen Pan
}

Cotton Economics Research Institute at Texas Tech University, Lubbock, Texas, USA

\begin{abstract}
This study analyzed two scenarios that considered a reduction of the US aggregate measure of supports (AMS) payments by $60 \%$ over a five-year period. In the first scenario, which considered a unilateral action by the US, the targeted AMS payments reduction would require a $12 \%$ cut in the US target price and an $8 \%$ cut in the loan rate. This would lead to a $3 \%$ decline in US cotton production, a $3 \%$ rise in world cotton price, and a $26 \%$ decline in US cotton net farm income at the end of the implementation period. The second scenario analyzed the case in which the US AMS payments reduction is concomitant with multilateral tariff and subsidy eliminations from the rest of the world. Under this scenario, fewer cuts in the US loan rate and target price (i.e. 9 and $4 \%$ ) were required to achieve the $60 \%$ AMS reduction because of market liberalization from the from the rest of the world. However, US cotton producers' net farm income still declined by $18 \%$.
\end{abstract}

Keywords: cotton; net farm income; subsidies; tariffs; United States; WTO

\section{Introduction}

The Ministerial Declaration that emerged from the recently concluded World Trade Organization (WTO) ministerial conference in Hong Kong continued the efforts of members to reform and liberalize the world cotton market '...ambitiously, expeditiously, and specifically' (WTO 2005). The special attention devoted to cotton serves as a recognition of the nexus between trade and development and the potential role cotton plays as an engine of economic growth for some of the world's least developed countries. The emphasis on cotton may indicate that agreement in this area would open the door to broader agreement on the agricultural sector in general.

*Corresponding author. Email: mohamadou.fadiga@ âttu.edu 
Before the Hong Kong Ministerial Conference, the Office of the US Trade Representative (USTR) floated a proposal advocating major reforms in all three areas of concern identified in the Doha Development Agenda (i.e. domestic support, market access, and export competition) by all member countries, with some 'special and differential treatment' for developing countries (USTR 2005). With respect to domestic support, the proposal included a $60 \%$ reduction in the final bound total aggregate measure of support (AMS) for the United States (from US\$19.2 billion to US\$7.6 billion) and an $83 \%$ reduction in the final bound total AMS for the European Union and Japan over a five-year period. For all other countries except the least developed, the proposed cut was $37 \%$ of the total bound AMS level. In the areas of market access and export competition, the proposal included deeper cuts for higher tariffs and complete elimination of all forms of export subsidies by 2010 for all products.

The Hong Kong Ministerial Declaration is, in principle, very similar to the US proposal. Both advocate eliminating all export subsidies, cutting tariffs, and reducing domestic support. While the Declaration is calling for the establishment of bands of AMS support and bands of tariff protection by which members offering higher levels of domestic support or higher tariff rates will be required to accept deeper cuts and reductions, it provides no specific thresholds or definitions of these bands. Further, there is no consensus regarding the level of cuts in each band.

Although the USTR cites significant support from the American agriculture sector for its proposal, the fundamental question that arises is whether improvements in market access around the world called for in the proposal would offset potential losses in US net farm income following substantial reduction in the AMS. Since an agreement is not yet finalized, the objective of this study is to analyze two scenarios in order to provide the upper and lower bounds of the possible effects of the agreement. A partial equilibrium econometric model of the world fiber market, developed by the Cotton Economics Research Institute (CERI) at Texas Tech University, was used to analyze the possible effects of these policy changes on the US and the world markets. The first scenario assumed the US would proceed unilaterally to cut its AMS payments to cotton producers requiring no trade reform or policy adjustments by any other trading partner. The model estimated the effects of the unilateral proposal on the world cotton price and US domestic cotton prices, polyester prices, government outlays, cotton production, mill use, exports, and net farm income. In the second scenario, a multilateral trade reform from the rest of the world goes along with cuts in US AMS payments. This means the elimination of import tariffs and cotton price supports internationally. The model estimated the effects of the multilateral scenario on the world cotton price, the US cotton sector, as well as cotton imports and exports of some of the world's leading cotton trading nations. 


\section{Conceptual framework}

The conceptual analysis of unilateral and multilateral reform in the US and world cotton markets builds on previous analysis of the effects of US cotton programs on the world market (Pan et al. 2005). Figure 1 shows the simultaneous effect on the world market of domestic support programs with an emphasis on the marketing loan programs of the United States and the effects of border policies including the Chinese tariff rate quota (TRQ). In panel [a] the loan rate plus the marketing loan benefit wedge $(L R+w)$ acts as a price floor for US cotton producers. The marketing loan benefit wedge (w) accounts for the effects of seasonality on price and the difference between posted county prices and national prices (Westhoff et al. 2005). Gardner (2002) evaluated the average marketing loan benefit wedge at $9 \%$ above the loan rate; thus, it is an important component of US producers' planting decision. As the price floor to which producers respond, the loan rate with the added marketing loan benefit wedge leads to a kinked US supply curve, which becomes inelastic below $L R+w$. The domestic price, $P d$, is found at the intersection of the kinked supply curve, $\mathrm{SK}_{0} \mathrm{~S}_{0}$ and demand curve D. Producers who participate in the loan program realize a marketing loan benefit equal to $L R+w-P d$ as long as the domestic price is below the loan rate. Under this policy scheme, total US supply is $Q_{\mathrm{S} 0}^{\mathrm{U}}$.

Panel [b] shows the domestic market of other cotton exporters (e.g. Australia, Brazil, Africa, and Uzbekistan). Panel [c] illustrates the effects of trade distorting policies on the world cotton market, mainly the domestic price support program in the US and China's import restricting TRQ. As part of its WTO accession commitments, China established a TRQ system for cotton imports with the current in-quota import level set at 890,000 metric tons and a tariff of $1 \%$ and an out-of-quota tariff rate of $40 \%$. As shown panel $[c]$ the US price support program causes the world excess supply curve (ES) to kink at the price support level $L R+w$ (given by point $K_{\mathrm{A}}$ in panel [c]). Similarly, excess demand is derived by taking into account the supply, demand, and border polices of major importing nations. As shown in panel [c], the world excess demand curve $\mathrm{ED}_{0}$ kinks because of the effects of the TRQ system China uses to limit its cotton imports. The TRQ system causes major distortions in the fiber cotton market because of China's place as the world largest cotton importer (Pan et al. 2005). The baseline condition in the world market is given by the excess supply curve ESES $_{0}$ and the excess demand curve $\mathrm{ED}_{0}$, from which we derive the world price level, $P_{\mathrm{W} 0}$. Total exports are $X_{\mathrm{S} 0}^{\mathrm{W}}$. In panel [b], exports from any given exporter at world cotton price $P_{\mathrm{W} 0}$ are $Q_{\mathrm{S} 0}^{\mathrm{E}}$. For cotton importing nations, panel [d], supply and demand quantities at $P_{\mathrm{W} 0}$ are $Q_{\mathrm{S} 0}^{\mathrm{I}}$ and $Q_{\mathrm{D} 0}^{\mathrm{I}}$.

Under the unilateral scenario, lowering the US target price and loan rate to achieve a $60 \%$ cut in AMS reduces the marketing loan benefit to US producers and moves the point of kink of the US cotton supply curve from 


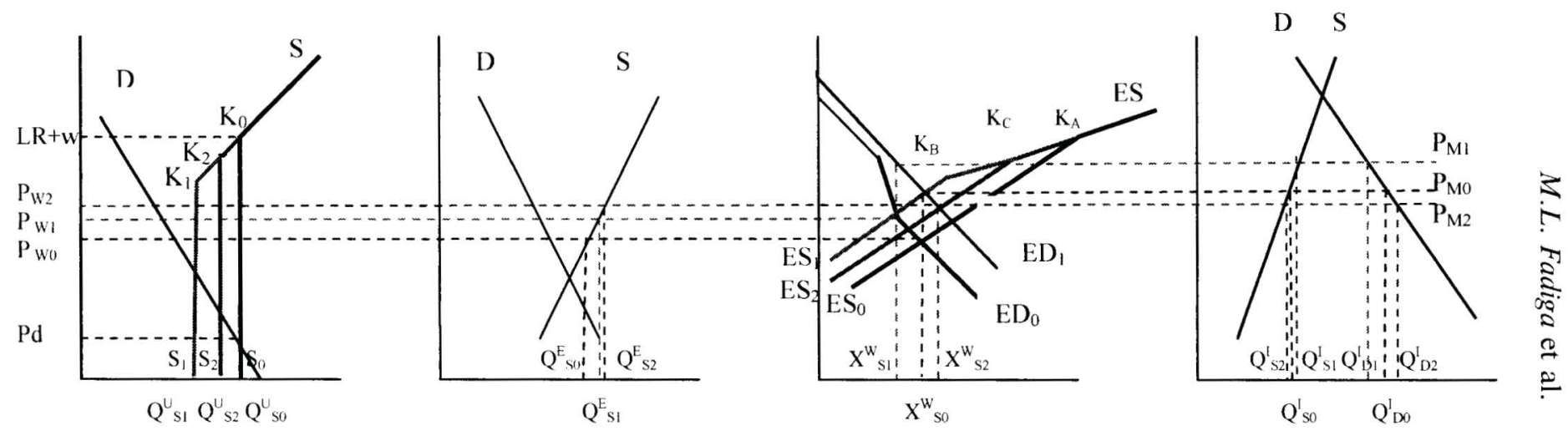
[a] U.S.
[b] Other Exporters
[c] World Market
[d] Importers

Figure 1. Effects of unilateral and multilateral reforms on the world cotton market. 
$K_{0}$ to $K_{1}$ (creating the effective supply curve $\mathrm{SS}_{1}$ ). US production declines from $Q_{\mathrm{S} 0}^{\mathrm{U}}$ to $Q_{\mathrm{S} 1}^{\mathrm{U}}$, which reduces US cotton exports. The lower US support price moves the kink in the world excess supply curve from $K_{\mathrm{A}}$ to $K_{\mathrm{B}}$, effectively causing a shift to the left in the world excess supply curve from ESES $_{0}$ to ESES 1 . The world price increases from $P_{\mathrm{W}_{0}}$ to $P_{\mathrm{W}_{1}}$ because of decreased supply in the world market. The quantity of cotton traded also declines from $X_{\mathrm{S} 0}^{\mathrm{W}}$ to $X_{\mathrm{S} 1}^{\mathrm{W}}$. However, nations competing with the US for export market share see their cotton exports increase in response to higher world prices $\left(Q_{\mathrm{S} 0}^{\mathrm{E}}\right.$ to $Q_{\mathrm{S} 1}^{\mathrm{E}}$, panel [b]). With a higher world cotton price, cotton importers (panel [d]) decrease imports by increasing domestic supply from $Q_{\mathrm{S} 0}^{\mathrm{I}}$ to $Q_{\mathrm{S} 1}^{\mathrm{I}}$ and decreasing quantity demanded from $Q_{\mathrm{D} 0}^{\mathrm{I}}$ to $Q_{\mathrm{D} 1}^{\mathrm{I}}$.

Under a multilateral trade liberalization scenario, the US can achieve the $60 \%$ AMS reduction with smaller cuts in the loan rate and target price. The US supply curve in this case kinks at point $K_{2}$ in panel [a] and the resulting domestic supply curve is given by line $\mathrm{SS}_{2}$. This level of US price support will cause the world excess supply curve to kink at point $K_{\mathrm{C}}$ with the new excess supply curve represented by ESES ${ }_{2}$. The elimination of border policies from importing countries leads to an unkinked excess demand curve, $E D_{1}$. The intersection of $E S E S_{2}$ and $E D_{1}$ represents the new market equilibrium. Comparing the multilateral scenario to the baseline condition and the unilateral scenario, the world price $\left(P_{\mathrm{W}_{2}}\right)$ is higher, world exports $\left(X_{\mathrm{S} 2}^{\mathrm{W}}\right)$ are greater, and cotton imports increase. US producers are better off under the baseline, are worse off under the unilateral scenario, and fall somewhere in between under the multilateral reform. This analysis provides expected directional changes in the measures discussed. The magnitude of these effects depends on the elasticity of the world excess demand and excess supply curves and requires empirical study to be ascertained.

\section{The model}

The World Fiber Model developed by the Cotton Economics Research Institute at Texas Tech University was used to estimate the effects of reform in domestic subsidies and trade barriers in the world cotton market. The model is described in detail in Pan et al. (2004). This partial equilibrium model included 24 countries and regions that encompass all major cotton exporters and importers. The model accounts for production area heterogeneity within some countries, substitutability between cotton and competing fibers, and linkage between raw fiber and the textilemanufacturing sector in both the US and the rest of the world. Figures 2 and 3 represent the schematic representations of the US and the rest of the world fiber models, respectively. These figures are described in detailed in Pan et al. (2005), which featured the Chinese and US textile models. 


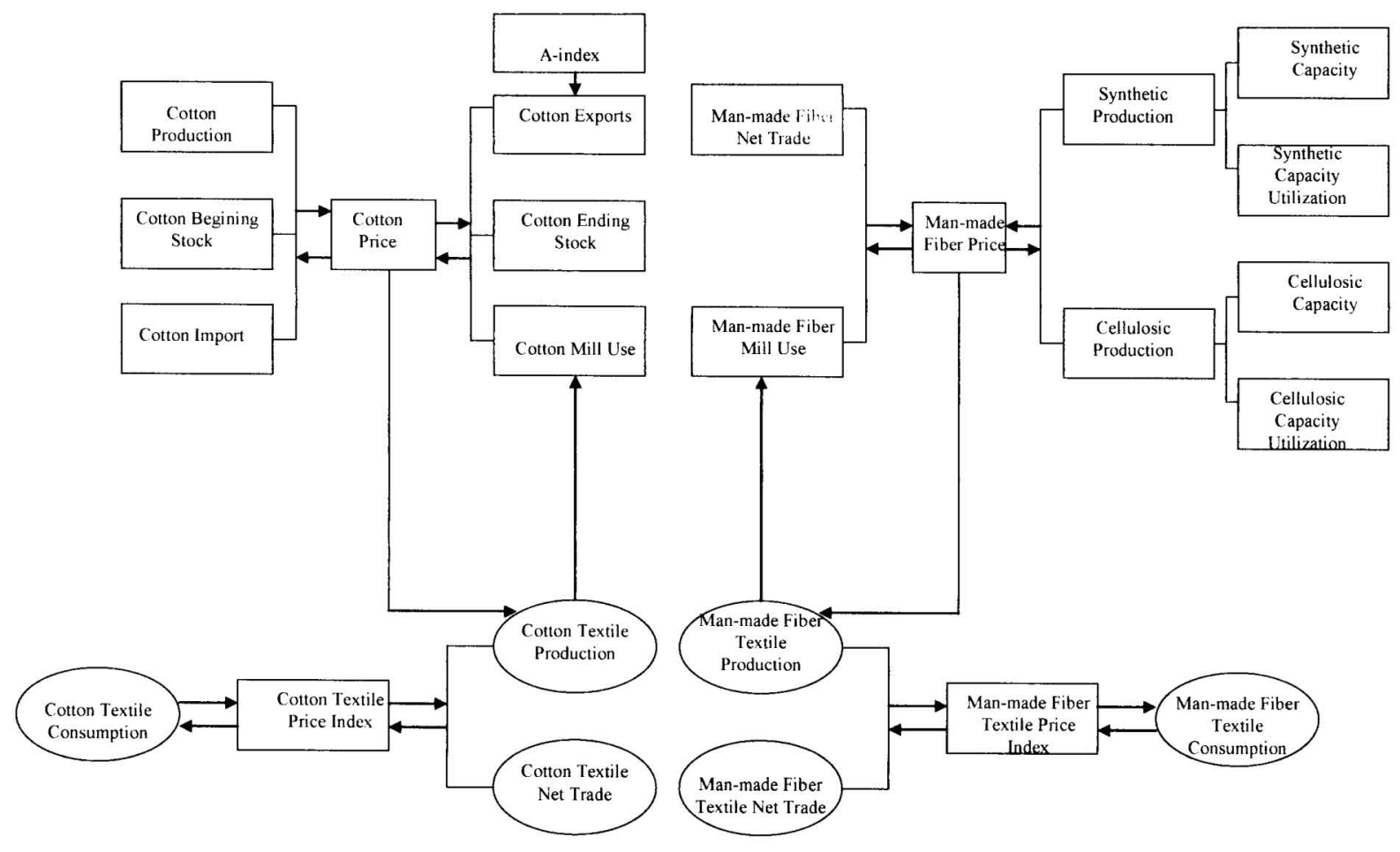

2
1
2
0
0
0
0
0
0
0

Figure 2. Schematic representation of the US fiber model. 


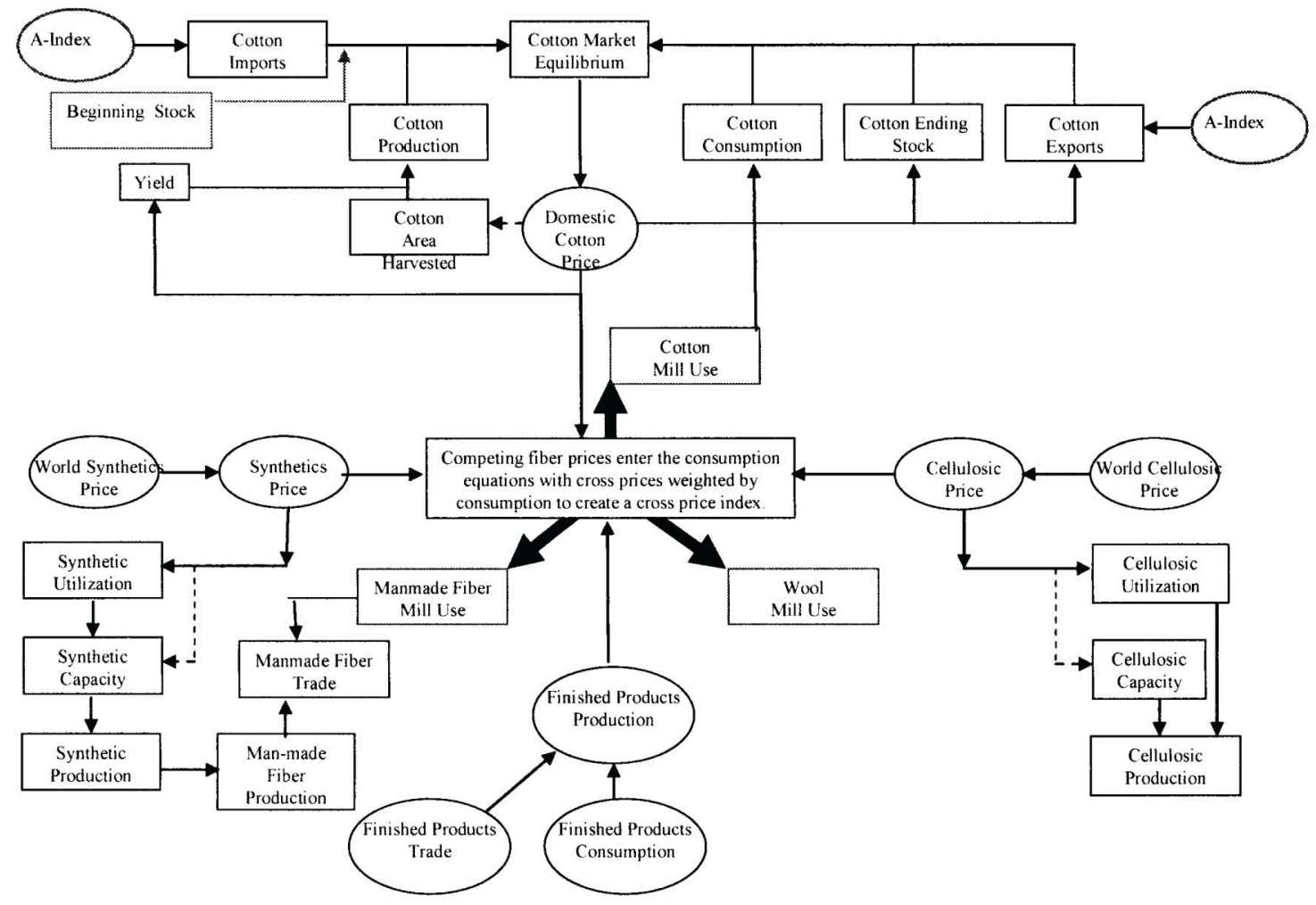

Figure 3. Schematic diagram of the rest of the world representative country fiber model. 
Thus, the representative rest of the world country and US textile model include supply, demand, ending stocks, and market equilibrium conditions for both cotton and man-made fibers. Cotton production $\left(P R D_{i}\right)$ was modeled using separate acreage $\left(A C R_{i}\right)$ and yield $\left(Y L D_{i}\right)$ equations. The acreage response model was specified as a function of the expected net return of cotton $\left(E N R_{i}^{c}\right)$, expected net returns of competing crops $\left(E N R_{i}^{o}\right)$, and a time trend $(T)$. Similarly, yield was specified as a function of the expected farm price $\left(F P R_{i}\right)$, a lag of rainfall $\left(L R F_{i}\right)$, and a time trend $(T)$.

Total production was obtained by multiplying yield by harvested area. The mathematical representation of the production model is as follows:

$$
\begin{gathered}
A C R_{i}^{c}=T^{\alpha_{i}}\left(E N R_{i}^{c}\right)^{\beta_{i}}\left(E N R_{i}^{o}\right)^{\gamma_{i}} \\
Y L D_{i}=T^{\phi_{i}}\left(F P R_{i}\right)^{\varphi_{i}}\left(L R F_{i}\right)^{\rho_{i}} \\
P R D_{i}^{c}=A C R_{i}^{c} \times Y L D_{i}^{c}
\end{gathered}
$$

Fiber demand estimation followed a two-step procedure that connects textile output to fiber inputs. The first step involved the estimation of total fiber demand $\left(D M_{i}^{f}\right)$ from which we derived the demand for all fibers. We calculated total fiber demand $\left(D M_{i}^{f}\right)$ as a function of a constant term representing autonomous fiber consumption $\left(D M_{i}\right)$, the fiber price index $\left(F P R_{i}\right)$, and gross domestic product $\left(G D P_{i}\right)$ :

$$
D M_{i}^{f}=D M_{i}\left(F P I_{i}\right)^{\sigma_{i}}\left(G D P_{i}\right)^{v_{i}}
$$

In the second step, we allocated total domestic textile production (equal to total fiber demand) among the various fibers (cotton, man-made fiber, and wool). For example, total cotton demand $\left(D M_{i}^{c}\right)$ is a function of the ratio of the domestic cotton price $\left(P D_{i}^{c}\right)$ and the domestic man-made fiber price $\left(P D_{i}^{m}\right)$ :

$$
D M_{i}^{c}=\left(P D_{i}^{c} / P D_{i}^{m}\right)^{\rho_{i}}
$$

We calculated demand for each fiber based on its utilization in the textile production process. We modeled man-made-fiber production $\left(P D R_{i}^{m}\right)$ using estimations of production capacity $\left(C P T_{i}\right)$ and capacity utilization $\left(C P U_{i}\right)$. Man made fiber production capacity was determined by the lag of the manmade-fiber domestic price $\left(L P D_{i}^{m}\right)$, the lag of the oil price $\left(L P D_{i}^{l}\right)$, and a lag of capacity $\left(L C P T_{i}^{m}\right)$ :

$$
C P T_{i}^{m}=\left(L P D_{i}^{l}\right)^{\eta_{i}}\left(L P D_{i}^{m}\right)^{\mu_{i}}\left(L C P T_{i}^{m}\right)^{\kappa_{i}}
$$


Total capacity utilization is a function of a ratio of the current domestic man-made-fiber price $\left(P D_{i}^{m}\right)$ and current oil price $\left(P D_{i}^{l}\right)$ and a lag of capacity utilization $\left(L C P U_{i}^{m}\right)$ :

$$
C P U_{i}^{m}=\left(P D_{i}^{m} / P D_{i}^{l}\right)^{\theta_{i}}\left(L C P U_{i}^{m}\right)^{\lambda_{i}}
$$

Multiplying production capacity by capacity utilization yields total manmade-fiber production:

$$
P R D_{i}^{m}=C P T_{i}^{m} \times C P U_{i}^{m}
$$

Cotton export demand $\left(X P D_{i}\right)$ was modeled as a function of the ratio of the international cotton price $\left(P_{W}\right)$ converted to domestic currency by the applicable exchange rate $\left(X R_{i}\right)$ and domestic cotton prices $\left(P D_{i}^{c}\right)$ :

$$
X P D_{i}=\left(P_{W} \times X R_{i} / P D_{i}^{c}\right)^{\varepsilon_{i}}
$$

The import demand equation $\left(I M D_{i}\right)$ for cotton was specified as a function of international cotton price, exchange rates, tariff rates $\left(t_{i}\right)$, and quota restrictions:

$$
I M D_{i}=\left(P_{W}\left(1+t_{i}\right) \times X R_{i}\right)^{\pi_{i}}
$$

Domestic market equilibrium is derived by equalizing demand and supply side equations that denote ending stocks plus domestic demand and exports that equal beginning stocks plus production and imports:

$$
E S_{i}+D M_{i}+X P D_{i}=B S_{i}+P R D_{i}+I M D_{i}
$$

Solving this equilibrium yielded the domestic price of cotton. Moreover, at the world level, total exports by all countries $\left(\sum_{i} X P D_{i}\right)$ equal total imports by all countries $\left(\sum_{i} I M D_{i}\right)$ :

$$
\sum_{i} X P D_{i}=\sum_{i} I M D_{i}
$$

The world cotton price (A-index), domestic cotton prices, cotton textile price index, non-cotton textile price index, farm price, and manmade fiber price were endogenously solved by equalizing world exports and imports.

There are noteworthy differences between countries in the model that impact supply estimations, namely the specification of the net return equation. In the US, net return values for cotton production and competing crops can be derived based on the available cost of production information. 
For most countries in the model, the cost of production information was not available. In such cases, the effective commodity price was used $\left(P S_{i}\right)$. Following Tokarick (2003), the effective price was derived from the domestic farm price $\left(F P R_{i}\right)$ and total production subsidies $\left(s_{i}\right)$ :

$$
P S_{i}=F P R_{i}\left(1+s_{i}\right)
$$

As mentioned previously, we modeled planting intentions (area equations) as a function of expected net returns for specific crops. For the US, expected net return $(E N R)$ is equal to the expected farm price $(E F P R)$ times yield $(Y L D)$ less total variable costs $(T V C)$ per acre plus farm policy support. Farm policy support includes expected countercyclical payments $(E C C P)$ and the expected marketing loan benefit rate $(E M L B)$ :

$$
E N R=E F P R \times Y L D-T V C+0.5 \times E C C P+E M L B
$$

Although countercyclical payments are not directly tied to production, we included them in the net return equation because decoupled payments have been shown to have some effects on planting decisions. However, we assumed that these payments are relevant to producers in making their planting decisions and accounted for their decoupling aspect by reducing their impact by one half. Studies by Westcott (2005), Sumner (2003), and Poonyth et al. (2004), and Westoff et al. (2005) provide a discussion on this issue and parameter estimates used to modify the impact of countercyclical payments. The expected countercyclical payment was derived by subtracting from the target price $(T P)$ the direct payment $(D P)$ and the higher of the loan rate $(L R)$ or the season average price $(L P D)$ multiplied by the farm's historic base yield:

$$
E C C P=[T P-D P-\max (L R, L P D)] \times B Y L D
$$

The expected marketing loan benefit rate is the loan rate less the loan repayment rate plus the previously defined marketing loan benefit wedge ( $w$ ) all multiplied by yield $(Y L D)$. The loan repayment rate is the lower of the loan rate or the adjusted world price $(A W P)$.

$$
E M L B=(L R-\min (L R, A W P)+w) \times L Y L D
$$

In the above specifications, the superscipts in greek letters are the coefficients to be estimated using historical data collected from various sources. The models were linearized by log transformations. Thus, the coeficients are the elasticities and may be interpreted as impact multipliers and determine the magnitudes of the simulation results. Detailed results of the 
estimation and the derived elasticity estimates are available in Pan et al. (2004) or from the authors upon request.

The data used in the study were compiled from various sources. The historical and predicted macroeconomic variables (real GDP, exchange rate, population, and GDP deflator) were obtained from the Food and Agricultural Policy Research Institute (FAPRI). Cotton production, consumption, ending stocks, imports, and export data were from US Department of Agriculture Production, Supply \& Distribution (PSD). Fiber mill consumption and man-made fiber data were from the Food and Agriculture Organization of the United Nations (FAO), World Fiber Consumption Survey (before 1994), and Fiber Organon (after 1994).

\section{Policy shock and assumptions}

We followed the familiar analytical approach of comparing alternative policy scenarios to a baseline estimation of prices and market conditions. Our five-year baseline covered cotton-marketing years 2006/07 to 2010/11 and assumed the continuation of current domestic and border protection policies. The first alternative scenario considered a $60 \%$ reduction of US AMs over a five-year period holding all other policies unchanged. The US was assumed to implement this policy unilaterally, that is without agreement by any other trading entity to alter its trading policy in any way. We measured the effects of unilateral policy implementation by comparing the world price, US farm price, government outlays, production, exports, mill use, and net farm income to their baseline values.

In the second alternative scenario, we combined the $60 \%$ reduction in US AMS with full trade liberalization from the rest of the world. All trading partners removed their border restrictions and ceased their domestic subsidy programs in exchange for the cuts in the US support programs. Again, we modeled trade reforms in this multilateral scenario over a five-year period instituting incremental linear cuts in tariff rates and subsidies. Policy effects were measured by comparing the baseline to revised estimates of the world cotton price, US farm price, US government outlays, world cotton production, world trade, world mill use, US net farm income, and changes in net cotton imports and exports by major players in the world cotton market.

Finally, we conducted a stochastic analysis of the effects of policy changes on the US net farm income to generate confidence bands and the cumulative distribution function of the changes with their associated probability levels. The stochastic simulation followed the same approach as in Fadiga et al. (2005). Based on a multivariate empirical distribution (Richardson et al. 2000) of historical exogenous data, this approach generated 500 correlated random draws of the exogenous variables. We substituted the exogenous variables into the partial equilibrium model to 
solve for the set of 500 endogenous variables, including US net farm income. The number of draws was set to 500 to be consistent with FAPRI's approach to stochastic analysis of agricultural commodities (FAPRI 2004). There is no limit on the number of exogenous stochastic variables to use to generate the draws; however, one has to be mindful of the computational cost associated with a large matrix. This study assumed that yields are at the basis of most of the uncertainty in the world fiber market; they were consequently used to generate the draws. In total, 29 yield variables, which correspond to the countries and regions that produce cotton, were used.

\section{Simulation results}

The first alternative scenario, unilateral trade reform, required a $12 \%$ cut in the US target price and an $8 \%$ cut in the loan rate to achieve the $60 \%$ AMS reduction threshold. In the second scenario, the multilateral trade reform, we reached the $60 \%$ AMS reduction by cutting the target price by $9 \%$ and the loan rate by $4 \%$. Because of the increased cotton price response in scenario 2 , we were able to achieve the proposed $60 \%$ AMS reduction goal in the multilateral reform scenario with smaller cuts in both the target price and the loan rate. Tables 1 and 2 report the results based on the unilateral scenario while Tables 3 through 5 report the findings under the multilateral settings.

\section{Scenario 1: Unilateral implementation}

Unilateral reduction in AMS resulted in a 3.5\% increase in the world cotton price and a $5 \%$ increase in the US farm price (Table 1). Loan deficiency payments decreased by $41 \%$ while countercyclical payments fell to zero by $2010 / 11$. Lower target prices and loan rates led to fewer cotton acres planted in the US and lower production of 700,000 bales per year (Table 2).

With fewer cotton acres and lower production, US cotton exports dropped by an average of $4 \%$ (Table 2 ), while higher cotton prices increased market revenue for US cotton producers. Gross revenue and net farm income fell because of substantial reductions in government payments. Lower net farm income begins in the first year of policy shocks and continues downward, declining by $26 \%$ in $2010 / 11$ (Table 2), The US treasury benefited from the price support cuts, saving almost $\$ 1$ billion per year in government payments (Table 1).

\section{Scenario 2: Multilateral trade reform}

As shown in Table 3, the world cotton price responded to multilateral trade reform with a $10.5 \%$ increase and the US farm price increased by $8.5 \%$, both substantially higher than in the unilateral scenario. The dynamics of 
Table 1. US proposal in a unilateral reform setting: impacts on cotton prices and government program payments.

\begin{tabular}{|c|c|c|c|c|c|c|}
\hline & $2006 / 07$ & $2007 / 08$ & $2008 / 09$ & $2009 / 10$ & $2010 / 11$ & Average \\
\hline \multicolumn{7}{|c|}{ (cents/pound) } \\
\hline \multicolumn{7}{|l|}{ A-index } \\
\hline Baseline & 60.91 & 62.64 & 64.16 & 64.59 & 64.49 & 63.36 \\
\hline $\begin{array}{l}\text { Unilateral } \\
\text { Reforms }\end{array}$ & 62.68 & 64.98 & 66.53 & 67.05 & 66.56 & 65.56 \\
\hline$\%$ Change & $2.91 \%$ & $3.74 \%$ & $3.71 \%$ & $3.81 \%$ & $3.21 \%$ & $3.47 \%$ \\
\hline \multicolumn{7}{|c|}{ US Farm Price } \\
\hline Baseline & 47.56 & 49.54 & 50.19 & 52.52 & 53.94 & 50.75 \\
\hline $\begin{array}{l}\text { Unilateral } \\
\text { Reforms }\end{array}$ & 48.97 & 51.67 & 52.74 & 56.01 & 57.28 & 53.34 \\
\hline$\%$ Change & $2.97 \%$ & $4.30 \%$ & $5.09 \%$ & $6.66 \%$ & $6.19 \%$ & $5.04 \%$ \\
\hline \multicolumn{7}{|c|}{ (SUS million) } \\
\hline \multicolumn{7}{|l|}{ LDP } \\
\hline Baseline & 1376.81 & 1304.25 & 1257.20 & 1267.19 & 1288.60 & 1298.81 \\
\hline $\begin{array}{l}\text { Unilateral } \\
\text { Reforms }\end{array}$ & 1119.83 & 942.46 & 808.02 & 729.55 & 761.12 & 872.20 \\
\hline$\%$ Change & $-18.66 \%$ & $-27.74 \%$ & $-35.73 \%$ & $-42.43 \%$ & $-40.93 \%$ & $-33.10 \%$ \\
\hline \multicolumn{7}{|l|}{$\mathrm{CCP}$} \\
\hline Baseline & 914.21 & 904.80 & 907.36 & 871.13 & 781.38 & 875.77 \\
\hline $\begin{array}{l}\text { Unilateral } \\
\text { Reforms }\end{array}$ & 780.26 & 568.78 & 386.88 & 65.53 & 0.00 & 360.29 \\
\hline$\%$ Change & $-14.65 \%$ & $-37.14 \%$ & $-57.36 \%$ & $-92.48 \%$ & $-100.00 \%$ & $-60.33 \%$ \\
\hline \multicolumn{7}{|l|}{ AMS Base } \\
\hline Baseline & 1930.00 & 1930.00 & 1930.00 & 1930.00 & 1930.00 & 1930.00 \\
\hline $\begin{array}{l}\text { Unilateral } \\
\text { Reforms }\end{array}$ & 1900.09 & 1511.24 & 1194.90 & 795.07 & 761.12 & 1232.48 \\
\hline$\%$ Change & $-1.55 \%$ & $-21.70 \%$ & $-38.09 \%$ & $-58.80 \%$ & $-60.56 \%$ & $-36.14 \%$ \\
\hline \multicolumn{7}{|c|}{ Government Outlays } \\
\hline Baseline & 3201.53 & 3119.56 & 3075.07 & 3048.83 & 2980.49 & 3085.10 \\
\hline $\begin{array}{l}\text { Unilateral } \\
\text { Reforms }\end{array}$ & 2810.60 & 2421.75 & 2105.42 & 1705.58 & 1671.64 & 2143.00 \\
\hline$\%$ Change & $-12.21 \%$ & $-22.37 \%$ & $-31.53 \%$ & $-44.06 \%$ & $-43.91 \%$ & $-30.82 \%$ \\
\hline
\end{tabular}

the changes were also noteworthy, increasing steadily through the first four years. Reductions in government outlays in the multilateral scenario matched those in the unilateral case.

Higher world and US farm prices in Scenario 2 resulted in US production and exports being relatively unchanged relative to the baseline (Table 4). However, projected US net farm income values still lay significantly below their baseline levels in the multilateral trade liberalization scenario (Table 4). From a $2 \%$ decrease at the beginning of the simulation period, losses in net farm income grew to $19 \%$ in five years. By these 
Table 2. US Proposal in a unilateral reform setting: impacts on the US cotton industry.

\begin{tabular}{|c|c|c|c|c|c|c|}
\hline & $2006 / 07$ & $2007 / 08$ & $2008 / 09$ & $2009 / 10$ & $2010 / 11$ & Average \\
\hline \multicolumn{7}{|c|}{ (Thousand of bales) } \\
\hline Production & & & & & & \\
\hline Baseline & 21853.82 & 21568.73 & 21720.82 & 21867.79 & 21969.75 & 21796.18 \\
\hline $\begin{array}{c}\text { Unilateral } \\
\text { Reforms }\end{array}$ & 21452.78 & 20979.08 & 20998 & 20984.35 & 21069.29 & 21096.70 \\
\hline$\%$ Change & $-1.84 \%$ & $-2.73 \%$ & $-3.33 \%$ & $-4.04 \%$ & $-4.10 \%$ & $-3.21 \%$ \\
\hline \multicolumn{7}{|l|}{ Exports } \\
\hline Baseline & 15843.74 & 16024.73 & 16627.31 & 17086.77 & 17236.13 & 16563.74 \\
\hline $\begin{array}{l}\text { Unilateral } \\
\text { Reforms }\end{array}$ & 15478.23 & 15458.71 & 15921.24 & 16237.32 & 16345.58 & 15888.21 \\
\hline$\%$ Change & $-2.31 \%$ & $-3.53 \%$ & $-4.25 \%$ & $-4.97 \%$ & $-5.17 \%$ & $-4.04 \%$ \\
\hline \multicolumn{7}{|l|}{ Mill-use } \\
\hline Baseline & 5988.55 & 5906.21 & 5850.79 & 5420.81 & 5241.26 & 5681.524 \\
\hline $\begin{array}{l}\text { Unilateral } \\
\text { Reforms }\end{array}$ & 5988.65 & 5905.00 & 5847.69 & 5414.03 & 5231.50 & 5677.374 \\
\hline$\%$ Change & $0.00 \%$ & $-0.02 \%$ & $-0.05 \%$ & $-0.13 \%$ & $-0.19 \%$ & $-0.08 \%$ \\
\hline \multicolumn{7}{|c|}{ (\$US million) } \\
\hline Net Farm Inc & ome & & & & & \\
\hline Baseline & 3840.28 & 3856.52 & 3812.86 & 3982.54 & 3965.21 & 3891.48 \\
\hline $\begin{array}{l}\text { Unilateral } \\
\text { Reforms }\end{array}$ & 3576.64 & 3338.52 & 3062.62 & 2935.18 & 2933.82 & 3169.36 \\
\hline$\%$ Change & $-6.87 \%$ & $-13.43 \%$ & $-19.68 \%$ & $-26.30 \%$ & $-26.01 \%$ & $-18.46 \%$ \\
\hline
\end{tabular}

estimates, multilateral reform only partially offsets lost net farm income experienced in the unilateral case.

Scenario 2 also estimated the effect of multilateral reform for major cotton trading nations around the world. For cotton importing countries the overall effects depended on the degree of protection that existed prior to trade liberalization. In China for instance, the elimination of the tariff rate quota system and production subsidies led to increased import demand. Chinese imports increased by an average of 7\% (800 thousand bales) relative to the baseline. Similar effects, although more modest, were noted for Pakistan and India. Turkey and the European Union provide subsidies to their producers, which if phased out, would decrease cotton production, especially in the case of the European Union where subsidies are much higher. The contraction in production led to more imports, averaging just over 3\% in Turkey and the European Union.

Countries with relatively low import duties do not benefit from higher international cotton prices. Korean, Taiwanese, and Japanese textile industries, which rely almost exclusively on imports for their operations, 
Table 3. US proposal in a multilateral reform setting: impacts on cotton prices and government payments.

\begin{tabular}{|c|c|c|c|c|c|c|}
\hline & $2006 / 07$ & $2007 / 08$ & $2008 / 09$ & $2009 / 10$ & $2010 / 11$ & Average \\
\hline \multicolumn{7}{|c|}{ (cents/pound) } \\
\hline \multicolumn{7}{|l|}{ A-index } \\
\hline Baseline & 60.91 & 62.64 & 64.16 & 64.59 & 64.49 & 63.36 \\
\hline $\begin{array}{c}\text { Multilateral } \\
\text { Reforms }\end{array}$ & 64.84 & 68.23 & 71.51 & 73.16 & 72.71 & 70.09 \\
\hline$\%$ Change & $6.47 \%$ & $8.92 \%$ & $11.46 \%$ & $13.28 \%$ & $12.74 \%$ & $10.57 \%$ \\
\hline \multicolumn{7}{|l|}{ US Farm Price } \\
\hline Baseline & 47.56 & 49.54 & 50.19 & 52.52 & 53.94 & 50.75 \\
\hline $\begin{array}{c}\text { Multilateral } \\
\text { Reforms }\end{array}$ & 50.13 & 53.47 & 54.63 & 58.07 & 59.34 & 55.13 \\
\hline$\%$ Change & $5.41 \%$ & $7.93 \%$ & $8.85 \%$ & $10.58 \%$ & $10.00 \%$ & $8.55 \%$ \\
\hline \multicolumn{7}{|c|}{ (\$US million) } \\
\hline \multicolumn{7}{|l|}{ LDP } \\
\hline Baseline & 1376.81 & 1304.25 & 1257.20 & 1267.19 & 1288.60 & 1298.81 \\
\hline $\begin{array}{c}\text { Multilateral } \\
\text { Reforms }\end{array}$ & 1152.09 & 984.58 & 826.58 & 748.91 & 776.09 & 897.65 \\
\hline$\%$ Change & $-16.32 \%$ & $-24.51 \%$ & $-34.25 \%$ & $-40.90 \%$ & $-39.77 \%$ & $-31.15 \%$ \\
\hline \multicolumn{7}{|l|}{$\mathrm{CCP}$} \\
\hline Baseline & 914.21 & 904.80 & 907.36 & 871.13 & 781.38 & 875.77 \\
\hline $\begin{array}{l}\text { Multilateral } \\
\text { Reforms }\end{array}$ & 797.59 & 549.91 & 387.01 & 74.62 & 0.00 & 361.83 \\
\hline$\%$ Change & $-12.76 \%$ & $-39.22 \%$ & $-57.35 \%$ & $-91.43 \%$ & $-100.00 \%$ & $-60.15 \%$ \\
\hline \multicolumn{7}{|l|}{ AMS Base } \\
\hline Baseline & 1930.00 & 1930.00 & 1930.00 & 1930.00 & 1930.00 & 1930.00 \\
\hline $\begin{array}{c}\text { Multilateral } \\
\text { Reforms }\end{array}$ & 1949.68 & 1534.48 & 1213.59 & 823.53 & 776.09 & 1259.48 \\
\hline$\%$ Change & $1.02 \%$ & $-20.49 \%$ & $-37.12 \%$ & $-57.33 \%$ & $-59.79 \%$ & $-34.74 \%$ \\
\hline \multicolumn{7}{|c|}{ Government Outlays } \\
\hline Baseline & 3201.53 & 3119.56 & 3075.07 & 3048.83 & 2980.49 & 3085.10 \\
\hline $\begin{array}{c}\text { Multilateral } \\
\text { Reforms }\end{array}$ & 2860.20 & 2445.00 & 2124.10 & 1734.04 & 1686.60 & 2169.99 \\
\hline$\%$ Change & $-10.66 \%$ & $-21.62 \%$ & $-30.92 \%$ & $-43.12 \%$ & $-43.41 \%$ & $-29.95 \%$ \\
\hline
\end{tabular}

each saw its cotton imports decline between 2 to $3 \%$. Of the major cotton importers reported here, the smallest impact from the US proposal was in Mexico. Mexican trade with the US is conducted in a free market environment due to the North American Free Trade Agreement, so the removal of cotton import tariffs in Mexico would spur a small increase in demand with other trading partners.

As for cotton exporters (Table 5), it was expected that the non- and lowsubsidizing countries would capture production displacement from 
Table 4. US proposal in a multilateral reform setting: impacts on U.S. cotton industry.

\begin{tabular}{|c|c|c|c|c|c|c|}
\hline & $2006 / 07$ & $2007 / 08$ & $2008 / 09$ & $2009 / 10$ & $2010 / 11$ & Average \\
\hline \multicolumn{7}{|c|}{ (Thousand bales) } \\
\hline \multicolumn{7}{|l|}{ Production } \\
\hline Baseline & 21853.82 & 21568.73 & 21720.82 & 21867.79 & 21969.75 & 21796.18 \\
\hline $\begin{array}{l}\text { Multilateral } \\
\text { Reforms }\end{array}$ & 21905.24 & 21564.13 & 21623.31 & 21646.17 & 21637.68 & 21675.3 \\
\hline$\%$ Change & $0.24 \%$ & $-0.02 \%$ & $-0.45 \%$ & $-1.01 \%$ & $-1.51 \%$ & $-0.55 \%$ \\
\hline \multicolumn{7}{|l|}{ Exports } \\
\hline Baseline & 15843.74 & 16024.73 & 16627.31 & 17086.77 & 17236.13 & 16563.74 \\
\hline $\begin{array}{l}\text { Multilateral } \\
\text { Reforms }\end{array}$ & 15895.19 & 15977.08 & 16527.29 & 16922 & 16934.06 & 16451.12 \\
\hline$\%$ Change & $0.32 \%$ & $-0.30 \%$ & $-0.60 \%$ & $-0.96 \%$ & $-1.75 \%$ & $-0.66 \%$ \\
\hline \multicolumn{7}{|l|}{ Mill-use } \\
\hline Baseline & 5988.55 & 5906.21 & 5850.79 & 5420.81 & 5241.26 & 5681.524 \\
\hline $\begin{array}{c}\text { Multilateral } \\
\text { Reforms }\end{array}$ & 6048.19 & 6004.71 & 5883.50 & 5406.15 & 5220.84 & 5712.679 \\
\hline$\%$ Change & $1.00 \%$ & $1.67 \%$ & $0.56 \%$ & $-0.27 \%$ & $-0.39 \%$ & $0.51 \%$ \\
\hline \multicolumn{7}{|c|}{ (\$US million) } \\
\hline \multicolumn{7}{|c|}{ Net Farm Income } \\
\hline Baseline & 3840.28 & 3856.52 & 3812.86 & 3982.54 & 3965.21 & 3891.48 \\
\hline $\begin{array}{l}\text { Unilateral } \\
\text { Reforms }\end{array}$ & 3772.65 & 3590.94 & 3324.30 & 3237.02 & 3215.99 & 3428.18 \\
\hline$\%$ Change & $-1.76 \%$ & $-6.89 \%$ & $-12.81 \%$ & $-18.72 \%$ & $-18.89 \%$ & $-11.82 \%$ \\
\hline
\end{tabular}

subsidizing and less cost competitive countries. Brazil gained the most, with increased cotton exports of over 10\%. Australia, West Africa, and Uzbekistan each increased exports around 5\%. For Brazil, the potential to expand cotton exports is great as more area in the frontier regions enter production in response to higher cotton prices. Much of Australian agriculture is constrained by reservoir collection of water resources. Water availability limits cotton production and thereby opportunities for expanded cotton exports. In West Africa, limited technological innovation and continued subjugation to weather variability prevents these countries from taking full advantage of higher prices.

\section{Comparison of probabilistic outcomes}

Figure 4 illustrates the probabilistic outcome of the changes in US net farm income under unilateral and multilateral settings in 2010/11, the year of full implementation of the $60 \%$ AMS reduction and trade reform. It is important to note the difference in the results obtained from the 
Table 5. US proposal in a multilateral reform setting: impacts on major cotton exporters.

\section{6/07 2007/08 2008/09 2009/10 2010/11 Average}

Australia

$\begin{array}{lcccccc}\text { Baseline } & 2859.96 & 2876.18 & 2794.36 & 2813.25 & 2860.43 & 2840.84 \\ \text { Multilateral Reforms } & 2985.54 & 3021.55 & 2944.06 & 2992.29 & 3085.16 & 3005.72 \\ \% \text { Change } & 4.39 \% & 5.05 \% & 5.36 \% & 6.36 \% & 7.86 \% & 5.80 \%\end{array}$

Brazil

$\begin{array}{lcccccc}\text { Baseline } & 2132.16 & 2831.67 & 3029.53 & 3269.68 & 3623.30 & 2977.27 \\ \text { Multilateral Reforms } & 2300.06 & 3102.20 & 3369.23 & 3651.89 & 4091.03 & 3302.88 \\ \text { \% Change } & 7.87 \% & 9.55 \% & 11.21 \% & 11.69 \% & 12.91 \% & 10.65 \%\end{array}$

Uzbekistan

Baseline

$\begin{array}{llllll}4495.75 & 4553.77 & 4585.97 & 4673.44 & 4712.16 & 4604.22\end{array}$

$\begin{array}{lllllll}\text { Multilateral Reforms } & 4686.32 & 4773.41 & 4825.80 & 4890.54 & 4941.80 & 4823.57\end{array}$

$\%$ Change

$4.24 \% \quad 4.82 \% \quad 5.23 \% \quad 4.65 \% \quad 4.87 \% \quad 4.76 \%$

West Africa

$\begin{array}{lllllll}\text { Baseline } & 3654.31 & 3820.23 & 3980.78 & 4109.05 & 4182.71 & 3949.42\end{array}$

$\begin{array}{lllllll}\text { Multilateral Reforms } 3825.20 & 4014.71 & 4201.32 & 4353.17 & 4441.34 & 4167.15\end{array}$

$\begin{array}{lllllll}\text { \% Change } & 4.68 \% & 5.09 \% & 5.54 \% & 5.94 \% & 6.18 \% & 5.49 \%\end{array}$

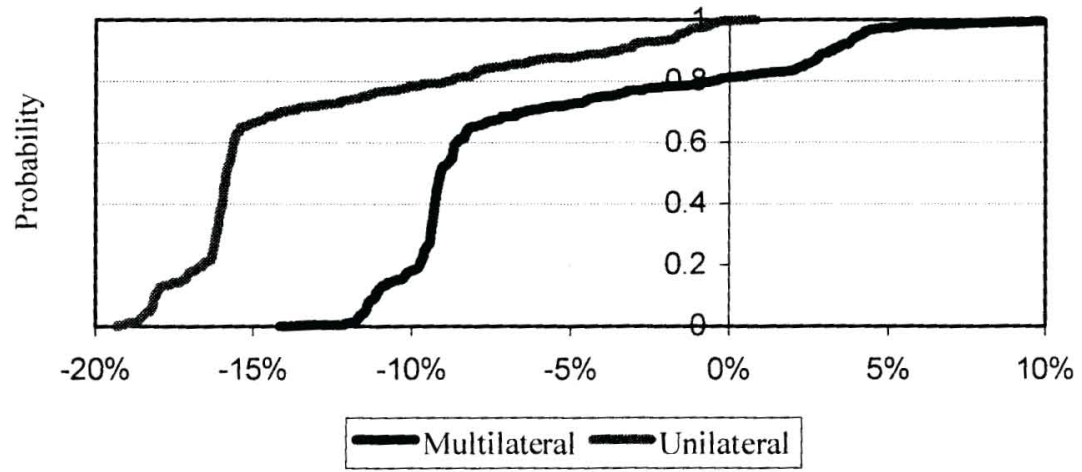

Figure 4. Cumulative distribution of change in US net farm income under unilateral versus multilateral action in 2010/11

deterministic analysis compared to the stochastic analysis. Under the unilateral scenario, the change in net farm income from the deterministic analysis was $-26.01 \%$, while the stochastic analysis yielded a $-13.48 \%$ change. Under the multilateral scenario, the deterministic and the stochastic means of the change in net farm income are $-18.89 \%$ and $-6.36 \%$, respectively. The deviation in the results pertains to the fact the deterministic 
analysis results are point estimates while the stochastic analysis are averages of 500 possible outcomes. The results show the probability of an increase in net farm income under the first scenario is close to zero. It is highly likely (a more than $60 \%$ chance) that net farm income would fall by more than $15 \%$. With multilateral reform, there was a $20 \%$ probability that the effect on net farm income would be positive and a $60 \%$ probability that net farm income would decrease by about $10 \%$ or more.

\section{Conclusions}

The US cotton farmers are bound to lose. The cost to US cotton producers of a $60 \%$ AMS reduction if the US acts unilaterally is much greater than if the policy initiative is accompanied with multilateral trade liberalization from other nations. If the US acts alone, a $12 \%$ cut in the target price and an $8 \%$ in the loan rate are necessary to meet the targeted AMS reduction. US net farm income decreases considerably because the moderate increase in US farm price cannot compensate for cutbacks in government payments. If the policy change is conducted along with multilateral trade liberalization from the rest of the world, lower cuts in the target price $(9 \%)$ and the loan rate $(4 \%)$ accomplish the policy objectives and the negative effects on US net farm income are somewhat mitigated. Net farm income is lower in the baseline in both scenarios: by an average of $26 \%$ in the first and $19 \%$ in the second. For the US competitors in the world cotton market, Brazil appears to be the primary beneficiary of the US proposal, followed by other leading cotton exporters Australia, West Africa, and Uzbekistan.

\section{References}

Fadiga, M.L., S. Mohanty, and S. Pan. 2005. The impacts of the U.S. cotton program on the west and central African countries cotton export earnings. Agricultural Economics Review 2: 50-60.

Food and Agricultural Policy Research Institute (FAPRI). 2004. FAPRI 2004 U.S. Baseline Briefing Book, FAPRI-UMC Technical Data Report 01-04 (University of Missouri).

Gardner, B. 2002. U.S. agricultural policies since 1995, with a focus on market effects in grains and oilseeds. Working Paper 02-17, Department of Agricultural and Resource Economics (University of Maryland).

Pan, S., M. Fadiga, S. Mohanty, and D. Ethridge. 2004. Structural models of the U.S. and rest-of-the-world natural fiber markets. Working Paper CER 04-03, Department of Agricultural and Applied Economics (Texas Tech University).

Pan, S., M. Welch, S. Mohanty, M.L. Fadiga, and D. Ethridge. 2005. Chinese tariff rate quota vs. U.S. subsidies: what affects the world cotton market more? Journal of International Law and Trade Policy 6, no. 2: 251-73. 
Poonyth, D., A. Sarris, R. Sharma, and S. Shui. 2004. The impact of domestic and trade policies on the world cotton market. Commodity and Trade Policy Research Working Paper No. 8 (Food and Agriculture Organization of the United Nations).

Richardson, J.W., S.L. Klose, and A.W. Gray. 2000. An applied procedure for estimating and simulating multivariate empirical probability distributions in farm-level risk assessment and policy analysis management. Journal of Agricultural and Applied Economics 32: 299-315.

Sumner, D. 2003. Implications of U.S. farm bill of 2002 for agricultural trade and trade negotiations. The Australian Journal of Agricultural and Resource Economics 46: 99-22.

Tokarick, S. 2003. Measuring the impact of distortions in agricultural trade in partial and general equilibrium. IMF Working Paper WP/03/110 (International Monetary Fund).

US Trade Representative 2005a. U.S. proposal for bold reform in global agriculture trade. Available online at http://www.ustr.gov.

Westcott, P. 2005. Counter-cyclical payments under the 2002 Farm Act: production effects likely to be limited. Choices 20: e201-e05.

Westhoff, P., S. Brown, and C. Hart. 2005. When point estimates miss the point: stochastic modeling of WTO restrictions. Food and Agricultural Policy Research Institute Working Paper \#01-05 (University of Missouri).

World Trade Organization. 2005. Doha Work Program. Draft Ministerial Declaration. Document Code TN/MIN (05)/W/3/Rev2 (The World Trade Organization). 